\title{
Comparative Effects of Food Preservatives on the Production of Staphylococcal Enterotoxin I from Staphylococcus aureus Isolate
}

\author{
Yanying Zhao, Anni Zhu, Junni Tang, Cheng Tang, and Juan Chen \\ College of life Science and Technology, Southwest University for Nationalities, Chengdu 610041, China \\ Correspondence should be addressed to Junni Tang; junneytang@aliyun.com
}

Received 6 November 2016; Revised 15 January 2017; Accepted 24 January 2017; Published 16 February 2017

Academic Editor: Rosa Pérez-Gregorio

Copyright (c) 2017 Yanying Zhao et al. This is an open access article distributed under the Creative Commons Attribution License, which permits unrestricted use, distribution, and reproduction in any medium, provided the original work is properly cited.

Staphylococcal enterotoxin I (SEI) is associated with staphylococcal food poisoning, but little is known about different food preservatives on the production of SEI. In this study, the effect of different food preservatives (sodium nitrite, polylysine, chitosan, and tea catechin) on the bacteria growth, sei gene expression, and extracellular SEI production of Staphylococcus aureus isolate H4 was detected in tryptone soya broth (TSB) culture. Our results showed that all of these preservatives depressed S. aureus $\mathrm{H} 4$ growth and the order of inhibitory effect was $0.8 \mathrm{~g} / \mathrm{L}$ tea catechin $>6 \mathrm{~g} / \mathrm{L}$ chitosan $>0.25 \mathrm{~g} / \mathrm{L}$ polylysine $>0.4 \mathrm{~g} / \mathrm{L}$ tea catechin $>0.15 \mathrm{~g} / \mathrm{L}$ sodium nitrite. Furthermore, $0.25 \mathrm{~g} / \mathrm{L}$ polylysine or $0.15 \mathrm{~g} / \mathrm{L}$ sodium nitrite did not significantly alter sei gene transcription, while $6 \mathrm{~g} / \mathrm{L}$ chitosan obviously increased the relative mRNA level of sei gene expression. $0.4 \mathrm{~g} / \mathrm{L}$ tea catechin remarkably inhibited sei gene transcription. In addition, $0.15 \mathrm{~g} / \mathrm{L}$ sodium nitrite and $6 \mathrm{~g} / \mathrm{L}$ chitosan significantly enhanced SEI secretion. $0.25 \mathrm{~g} / \mathrm{L}$ polylysine, especially $0.4 \mathrm{~g} / \mathrm{L}$ tea catechin, sharply inhibited the level of SEI secretion. The results indicated that tea catechin not only suppressed Staphylococcus aureus growth, but also inhibited SEI production and secretion, suggesting that tea catechin may be better than sodium nitrite, polylysine, or chitosan for keeping the food from the contamination of SEI. These investigations would be useful for food industry to provide safer food products due to $S$. aureus enterotoxins-related control strategy.

\section{Introduction}

Staphylococcus aureus (S. aureus) is a major bacterial pathogen that causes clinical infection and foodborne illnesses [1]. The organism is robust, which permits it to grow in many types of foods improperly prepared or stored and to produce staphylococcal enterotoxins (SEs). SEs are the causative agents of staphylococcal food poisoning (SFP) [2]. Even though the bacteria can be killed through heat treatment of the food, the SEs are heat-resistant. Thus, although the bacteria are eliminated, the toxins will remain in food and subsequently cause SFP [3].

To date, more than twenty-four SEs and staphylococcal enterotoxin-like proteins (SEls) have been identified and designated SEA to SElY [4-6]. These SEs/SEls have been traditionally subdivided into classical (SEA to SEE) and new type (SEG to SElY). It is supposed that SEs are the toxins that elicit emesis; the related SEls either lack emetic activity or have not yet been examined [4]. In recent years, several studies indicate that SEG and SEI may be responsible for cases of SFP in humans [7-9]. However, commercial kits for immunological detection of SEI protein are not available currently $[10,11]$. Thus, there is very limited data on the production of SEI.

Food preservatives are widely used to reduce the risk of food poisoning. Conventional preservatives are synthetic chemical substances such as sodium nitrite, sodium benzoate, and potassium sorbate. Because of side effects, the use of artificial preservatives is being reconsidered [12]. With growing consumer demand for natural preservatives to replace chemical compounds, new antimicrobial products of various origins are being developed, including animal-derived products (lysozymes, lactoperoxidase, chitosan, antimicrobial peptide, and others), plant-derived products (polyphenolics, essential oils, plant antimicrobial peptides, and others), and microbial metabolites (nisin, natamycin, $\varepsilon$-polylysine, organic acid, and 
others). These products must be investigated for the potential to control foodborne pathogens in foods.

In this study, comparative effects of several food preservatives: sodium nitrite, polylysine, chitosan, and tea catechin on bacteria growth, sei gene expression, and extracellular SEI secretion from a penicillin-resistant $S$. aureus isolate $\mathrm{H} 4$ associated with food poisoning were detected to assess these products for use as antimicrobial agents in food preservation.

\section{Materials and Methods}

2.1. Bacterial Plate Counting. S. aureus strain H4 (penicillinresistant) was isolated from vomitus of hospitalized patient associated with food poisoning in Chongqing, China [13]. $2 \times 10^{5} \mathrm{CFU} S$. aureus $\mathrm{H} 4$ was inoculated in $250 \mathrm{~mL}$ tryptone soya broth (TSB) medium supplemented with different food preservatives at maximum permissible concentrations ( $0.15 \mathrm{~g} / \mathrm{L}$ sodium nitrite, Sichuan Jinshan Pharmaceutical Co., Ltd., China; 0.25 g/L polylysine, Zhengzhou Tianfeng Food Science and Technology Co., Ltd., China; $6 \mathrm{~g} / \mathrm{L}$ chitosan, Zhengzhou Tianhe Biological Science and Technology Co., Ltd., China; and $0.8 \mathrm{~g} / \mathrm{L}$ tea catechin, Zhengzhou Green Banko Trade Ltd., China) according to Food Safety Law of the People's Republic of China (GB2760-2014). In addition, $0.075 \mathrm{~g} / \mathrm{L}(1 / 2 \mathrm{x})$ and $0.0375 \mathrm{~g} / \mathrm{L}(1 / 4 \mathrm{x})$ sodium nitrite; $0.125 \mathrm{~g} / \mathrm{L}$ $(1 / 2 \mathrm{x})$ and $0.0625 \mathrm{~g} / \mathrm{L}(1 / 4 \mathrm{x})$ polylysine; $3 \mathrm{~g} / \mathrm{L}(1 / 2 \mathrm{x})$ and $1.5 \mathrm{~g} / \mathrm{L}(1 / 4 \mathrm{x})$ chitosan; and $0.4 \mathrm{~g} / \mathrm{L}(1 / 2 \mathrm{x})$ and $0.2 \mathrm{~g} / \mathrm{L}(1 / 4 \mathrm{x})$ tea catechin were also used. After incubation at $37^{\circ} \mathrm{C}$ with shaking at 150 revolutions per minute (rpm) for 24 hours, $1 \mathrm{~mL}$ cell suspension was collected for viable plate counting and the best doses of the food preservatives were chosen. Then $2 \times 10^{5} \mathrm{CFU}$ S. aureus $\mathrm{H} 4$ was inoculated in $250 \mathrm{~mL}$ TSB medium containing the food preservative at the best concentration for 12,24 , and 48 hours, respectively. $1 \mathrm{~mL}$ cell suspension was also harvested for viable plate counting.

2.2. Real Time Quantitative PCR. Real time quantitative PCR was employed to detect relative mRNA level of sei in $S$. aureus $\mathrm{H} 4$ treated with food preservatives. After incubation for 24 hours, $200 \mathrm{~mL}$ cell suspension was collected and centrifuged at $10,000 \mathrm{~g}$ for $15 \mathrm{~min}$. The supernatant was harvested for the following SEI protein quantification and the cells were lysed by TE buffer $(10 \mathrm{mmol} / \mathrm{L}$ Tris- $\mathrm{HCl}, 1 \mathrm{mmol} / \mathrm{L}$ EDTA, $\mathrm{pH}=8.0)$ supplemented with $3 \mathrm{mg} / \mathrm{mL}$ lysozyme. Total RNA was extracted with TRIzol ${ }^{\circledR}$ reagent (Tiangen, Beijing, China) according to the product protocol. The concentration of RNA was detected in a spectrophotometer (Biowave II, Biochrom, UK) and $2 \mu \mathrm{g}$ RNA was used to synthesize cDNA by reverse transcription with a PrimeScript ${ }^{\circledR}$ RT reagent Kit (Fermentas Life Science, Hanover, MD, US) as described in the manufacturer's instructions.

Real time fluorescence-based quantitative PCR was performed in a fluorescence temperature iCycler (Bio-Rad, Hercules, CA, USA). The specific primers for sei gene that we previously cloned (GenBank accession number: KT853046.1) were sei-qF: 5'-TGCCTTTACCAGTGTTATT-3' and seiqR: $5^{\prime}$-AGGACAATACTTAAATTCTGCT- $3^{\prime}$. These primers were designed with Primer Premier 5.0 software and the specificity of the primers was assayed by PCR. Conditions for
PCR amplification were $120 \mathrm{~s}$ at $95^{\circ} \mathrm{C}$, followed by 39 cycles of $10 \mathrm{~s}$ at $95^{\circ} \mathrm{C}, 30 \mathrm{~s}$ at $55^{\circ} \mathrm{C}$, and $30 \mathrm{~s}$ at $72^{\circ} \mathrm{C}$. The threshold cycle (CT) was analyzed with a $2^{-\Delta \Delta \mathrm{Ct}}$ method [14]. FtsZ (primers: FtsZ-F $5^{\prime}$-TGAAGATGCAATCCAAGGTG- ${ }^{\prime}$ and FtsZ-R $5^{\prime}$-GTTAATGCGCCCATTTCTTT- $3^{\prime}$ ) was used as a loading control for normalization.

2.3. Double-Antibody Sandwich ELISA. Double-antibody sandwich ELISA was developed for detecting SEI secretion from $S$. aureus $\mathrm{H} 4$ with food preservative administration as previously described [13]. In brief, $2.89 \mu \mathrm{g} / \mathrm{mL}$ monoclonal antibody against SEI in PBS was coated into microtiter plate overnight at $4^{\circ} \mathrm{C}$; the plate was blocked with $5 \%$ skimmed milk in PBS at $37^{\circ} \mathrm{C}$ for $60 \mathrm{~min}$. $0.1 \mathrm{~mL}$ supernatant of $S$. aureus $\mathrm{H} 4$ collected at the 24th hour was added to each well at $37^{\circ} \mathrm{C}$ for $60 \mathrm{~min}$, washed extensively with PBS containing $0.05 \%$ Tween-20, followed by incubation with $0.1 \mathrm{~mL}$, polyclonal antibody against SEI (dilution $1: 1000$ ) at $37^{\circ} \mathrm{C}$ for $60 \mathrm{~min}$, and washed again. Then, $0.1 \mathrm{~mL}$, goat anti-rabbit IgG-horseradish peroxidase (dilution 1:6000, Santa Cruz, USA) was added to each well at $37^{\circ} \mathrm{C}$ for $60 \mathrm{~min}$ and washed again. Thereafter, $0.1 \mathrm{~mL}$ of substrate tetramethylbenzidine (TMB) solution was used, and, finally, $\mathrm{H}_{2} \mathrm{SO}_{4}$ was employed to terminate reaction. The measurement was carried out at $450 \mathrm{~nm}$ photometrically.

2.4. Statistical Analysis. Data were presented as mean \pm SEM and the differences between food preservatives treatments and controls were statistically analyzed using SPSS13.0 (SPSS, Chicago, IL, USA).

\section{Results}

3.1. Bacterial Plate Counting. The number of S. aureus $\mathrm{H} 4$ with different food preservative treatments was determined by viable plate counting as shown in Figure 1. All of these preservatives depressed $S$. aureus $\mathrm{H} 4$ growth, especially at maximum permissible concentrations (Figure 1(a)). It is noteworthy to mention that $0.8 \mathrm{~g} / \mathrm{L}$ tea catechin absolutely disrupted bacteria after 24-hour incubation; thus, the concentration of tea catechin was adjusted to $0.4 \mathrm{~g} / \mathrm{L}$. Thereafter, the best dose of the food preservative for the following study or comparison was $0.15 \mathrm{~g} / \mathrm{L}$ sodium nitrite, $0.25 \mathrm{~g} / \mathrm{L}$ polylysine, $6 \mathrm{~g} / \mathrm{L}$ chitosan, and $0.4 \mathrm{~g} / \mathrm{L}$ tea catechin. The order of inhibitory effect was $6 \mathrm{~g} / \mathrm{L}$ chitosan $>0.25 \mathrm{~g} / \mathrm{L}$ polylysine $>0.4 \mathrm{~g} / \mathrm{L}$ tea catechin $>0.15 \mathrm{~g} / \mathrm{L}$ sodium nitrite from 12 - to 48-hour incubation (Figure 1(b)). Therefore, it seemed that natural preservatives: chitosan, polylysine, and tea catechin were more efficient than chemical compound sodium nitrite in inhibiting $S$. aureus growth.

\subsection{Effect of Food Preservatives on sei Gene Transcription.} Furthermore, relative mRNA level of sei gene expression in S. aureus $\mathrm{H} 4$ was detected by real time quantitative PCR. The results indicated that $0.25 \mathrm{~g} / \mathrm{L}$ polylysine $(0.91 \pm 0.12$ versus $1.03 \pm 0.3, p=0.207)$ or $0.15 \mathrm{~g} / \mathrm{L}$ sodium nitrite $(0.73 \pm 0.16$ versus $1.03 \pm 0.3, p=0.56)$ did not significantly alter sei gene transcription, while $6 \mathrm{~g} / \mathrm{L}$ chitosan $(2.29 \pm 0.23$ versus $1.03 \pm 0.3, p=0.0046$ ) obviously increased the relative mRNA 


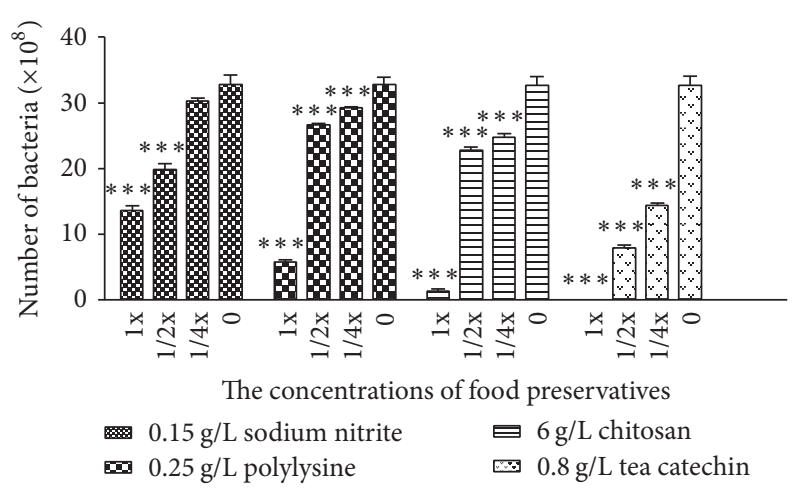

(a)

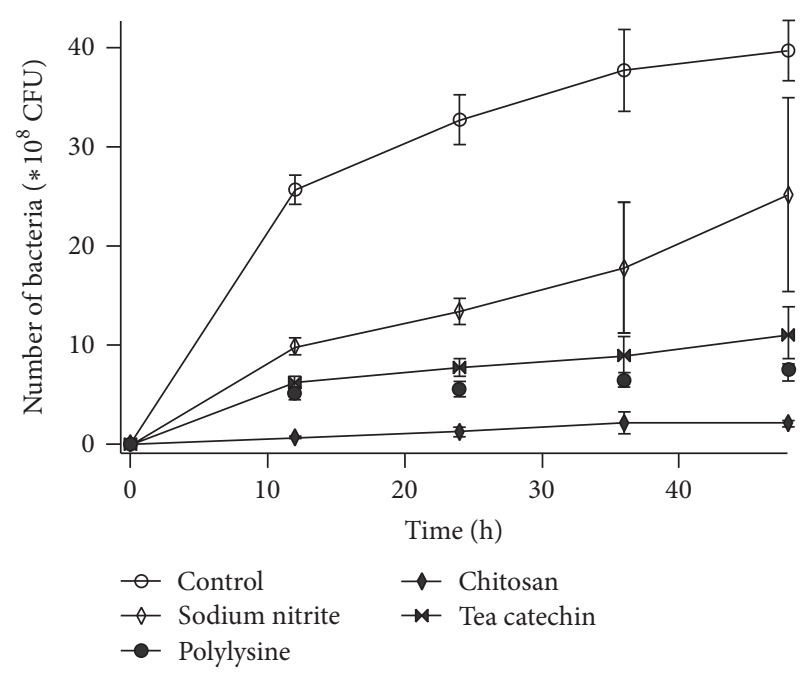

(b)

FIGURE 1: Viable plate count of penicillin-resistant S. aureus strain $\mathrm{H} 4$ treated with different food preservatives. (a) $2 \times 10^{5} \mathrm{CFU}$ S. aureus $\mathrm{H} 4$ was inoculated in $250 \mathrm{~mL}$ TSB medium supplemented with $0.15 \mathrm{~g} / \mathrm{L}(1 \mathrm{x}), 0.075 \mathrm{~g} / \mathrm{L}(1 / 2 \mathrm{x})$, or $0.0375 \mathrm{~g} / \mathrm{L}(1 / 4 \mathrm{x})$ sodium nitrite; $0.25 \mathrm{~g} / \mathrm{L}(1 \mathrm{x})$, $0.125 \mathrm{~g} / \mathrm{L}(1 / 2 \mathrm{x})$, or $0.0625 \mathrm{~g} / \mathrm{L}(1 / 4 \mathrm{x})$ polylysine; $6 \mathrm{~g} / \mathrm{L}(1 \mathrm{x}), 3 \mathrm{~g} / \mathrm{L}(1 / 2 \mathrm{x})$, or $1.5 \mathrm{~g} / \mathrm{L}(1 / 4 \mathrm{x})$ chitosan; and $0.8 \mathrm{~g} / \mathrm{L}(1 \mathrm{x}), 0.4 \mathrm{~g} / \mathrm{L}(1 / 2 \mathrm{x})$, or $0.2 \mathrm{~g} / \mathrm{L}$ $(1 / 4 \mathrm{x})$ tea catechin, respectively. After incubation at $37^{\circ} \mathrm{C}$ for 24 hours, $1 \mathrm{~mL}$ cell suspension was collected for viable plate count. (b) $2 \times 10^{5} \mathrm{CFU}$ S. aureus $\mathrm{H} 4$ was inoculated in $250 \mathrm{~mL}$ TSB medium supplemented with $0.15 \mathrm{~g} / \mathrm{L}$ sodium nitrite, $0.25 \mathrm{~g} / \mathrm{L}$ polylysine, $6 \mathrm{~g} / \mathrm{L}$ chitosan, or $0.4 \mathrm{~g} / \mathrm{L}$ tea catechin for 12,24 , and 48 hours, respectively. Data were the mean \pm SEM of three independent experiments $\left({ }^{* * *} p<0.001\right)$.

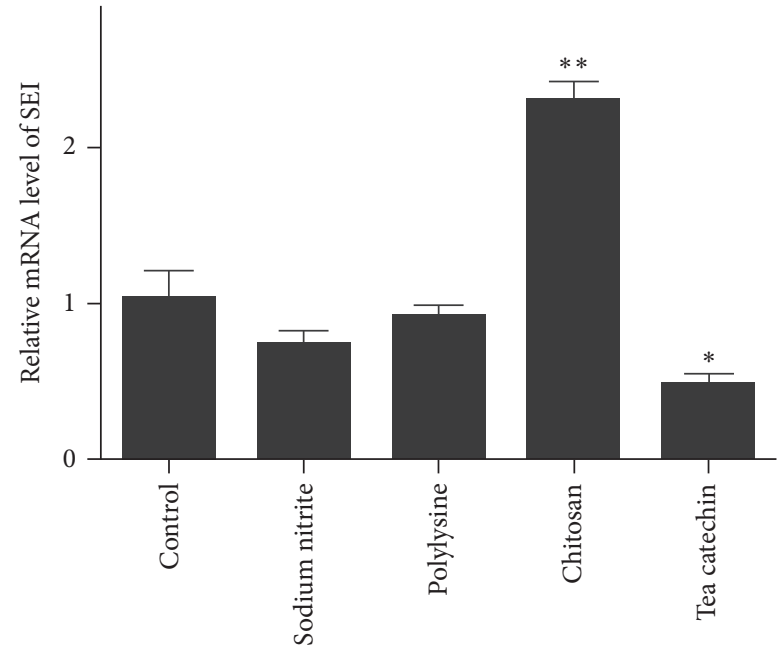

FigURE 2: Effect of different food preservatives on sei gene transcription. $S$. aureus $\mathrm{H} 4$ was treated with sodium nitrite, polylysine, chitosan, or tea catechin, respectively, as described above. At the 24th-hour incubation, $S$. aureus were lysed by lysozyme and the mRNA was detected by real time quantitative PCR. Data were the mean \pm SEM of three independent experiments $\left({ }^{*} p<0.05,{ }^{* *} p<\right.$ $0.01)$.

level of sei gene expression. $0.4 \mathrm{~g} / \mathrm{L}$ tea catechin remarkably inhibited sei gene transcription $(0.48 \pm 0.11$ versus $1.03 \pm 0.3$, $p=0.043$ ) (Figure 2). Thus, only tea catechin prevented sei transcription.

3.3. Influence of Different Food Preservatives on Extracellular SEI Production. In addition, the extracellular SEI production was tested by double-antibody sandwich ELISA. As shown in Figure 3(a), $0.15 \mathrm{~g} / \mathrm{L}$ sodium nitrite $\left(8.80 \pm 1.41 \times 10^{-9} \mathrm{ng} / \mathrm{cell}\right.$ versus $3.54 \pm 0.04 \times 10^{-9} \mathrm{ng} /$ cell, $\left.p=0.038\right)$ and $6 \mathrm{~g} / \mathrm{L}$ chitosan $\left(9.40 \pm 0.42 \times 10^{-9} \mathrm{ng} /\right.$ cell versus $3.54 \pm 0.04 \times 10^{-9} \mathrm{ng} /$ cell, $p=0.0034)$ significantly enhanced SEI secretion; SEI protein increment by chitosan was consistent with the result of PCR, while $0.25 \mathrm{~g} / \mathrm{L}$ polylysine $\left(2.90 \pm 0.14 \times 10^{-9} \mathrm{ng} /\right.$ cell versus $3.54 \pm 0.04 \times 10^{-9} \mathrm{ng} /$ cell, $\left.p=0.043\right)$, especially $0.4 \mathrm{~g} / \mathrm{L}$ tea catechin $\left(1.70 \pm 0.07 \times 10^{-9} \mathrm{ng} /\right.$ cell versus $3.54 \pm 0.04 \times$ $10^{-9} \mathrm{ng} /$ cell, $\left.p=0.0008\right)$, sharply inhibited the level of SEI secretion. Among these food preservatives, tea catechin not only downregulated sei gene transcription, but also depressed its protein secretion. On the other hand, except sodium nitrite, all of the three natural food preservatives remarkably decreased total extracellular concentration of SEI in TSB culture (Figure 3(b)).

\section{Discussion}

Nowadays, consumers want more convenient, ready-to-eat food. Convenient food offers a suitable growth environment for S. aureus, an important pathogen associated with foodborne diseases including toxic shock syndrome and food poisoning by secreting a wide variety of SEs/SEls [15]. In order to produce high-quality, microbiologically safe food for consumers, data on SEs/SEls production in food preservatives environments are needed to improve existing understanding about the growth and survivability of $S$. aureus in liquid cultures.

In this study, we evaluated the effects of sodium nitrite, polylysine, chitosan, and tea catechin on the growth of $S$. aureus $\mathrm{H} 4$. All of tested preservatives inhibited bacterial 


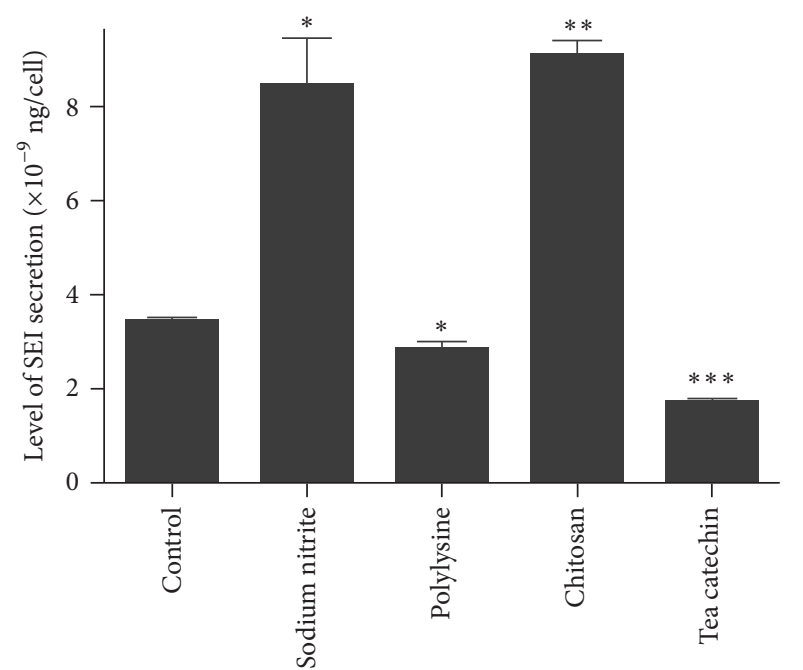

(a)

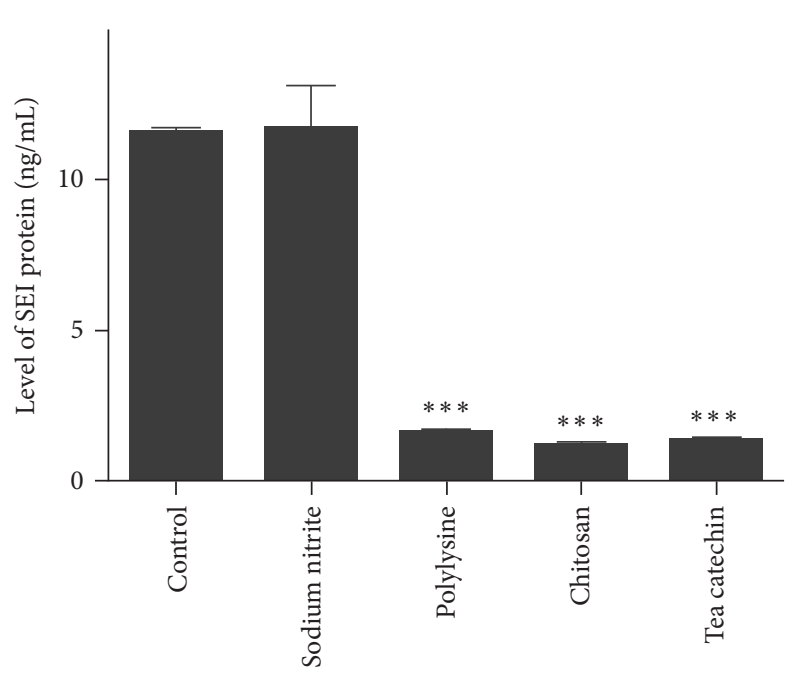

(b)

FIGURE 3: Influence of different food preservatives on extracellular SEI secretion. S. aureus H4 was administrated with sodium nitrite, polylysine, chitosan, or tea catechin, respectively, as described above. At the 24th-hour incubation, the level of SEI in supernatant of S. aureus H4 was tested by double-antibody sandwich ELISA. (a) The level of SEI produced by per bacterium. (b) The concentration of total extracellular SEI $\left({ }^{*} p<0.05,{ }^{* *} p<0.01\right.$, and $\left.{ }^{* * *} p<0.001\right)$.

growth and $0.8 \mathrm{~g} / \mathrm{L}$ tea catechin was lethal to $S$. aureus. After $24 \mathrm{~h}$ incubation, the numbers of bacterial cells were as control $>0.15 \mathrm{~g} / \mathrm{L}$ sodium nitrite $>0.4 \mathrm{~g} / \mathrm{L}$ tea catechin $>0.25 \mathrm{~g} / \mathrm{L}$ polylysine $>6 \mathrm{~g} / \mathrm{L}$ chitosan. It seemed that the three natural food preservatives were more effective in inhibiting bacterial growth than the chemical food preservative sodium nitrite at these concentrations.

Furthermore, sei expression was investigated by real time quantitative PCR and ELISA method, respectively. The traditional point was that SEs production was correlated with bacterial growth, the more bacterial cells, and the more toxins. Thus, the number of bacterial cells was usually counted to determine the level of SEs production. In our study, tea catechin, polylysine, and chitosan indeed reduced the total content of SEI, which was consistent with the decrement of bacterial cell numbers. Even though sodium nitrite inhibited $S$. aureus growth, it did not decrease SEI production, which indicated that bacterial growth and SEI production was decoupled. Chitosan, a linear biopolymer composed of $\beta$-(1-4)-linked N-acetyl-D-glucosamine, is a deacetylated derivative of chitin [16]. Chitosan has been recommended as a potential candidate for targeting antimicrobial agents due to a broad spectrum of antimicrobial activity and biocompatibility [17-19]. In this study, chitosan had a good inhibitory effect on the bacterial growth and had the potential to control bacterial cell number; however, it increased the relative mRNA level of sei gene expression and enhanced the SEI secretion, which indicated that chitosan might be not effective to control the staphylococcal enterotoxins production.

On the other hand, polyphenols in tea include catechins, flavonoids, tannins, and theaflavins. These compounds provide potential health benefits [20]. Catechins are composed of epigallocatechin-3-gallate (EGCG), epicatechin, epicatechin3 -gallate, and epigallocatechin. The main active ingredient EGCG accounts for approximately $59 \%$ of the total catechins [21]. A report suggested that negatively charged EGCG exerts its antibactericidal activity by binding to the positively charged lipids of the bacterial cell membrane, leading to damage to the lipid layer $[22,23]$. Another report indicated that tea catechin EGCG inhibited SEB production in dose and time dependent manner [24]. Further work is needed to determine the effects of tea catechin EGCG on different SE production and whether EGCG has neutralization properties against other staphylococcal superantigens. In our experiment, tea catechin not only sharply inhibited $S$. aureus $\mathrm{H} 4$ growth, but also depressed sei mRNA and protein production, which was consistent with Hisano's report.

Taken together, we detected and compared the effects of food preservatives: sodium nitrite, polylysine, chitosan, and tea catechin on penicillin-resistant $S$. aureus $\mathrm{H} 4$ growth and SEI production. Our results indicated that natural preservatives exerts higher antibacterial activity than chemical compound and tea catechin was the most efficient among the four kinds of food preservatives in inhibiting S. aureus growth and SEI production. The investigation was useful for food industry to provide safer food products due to $S$. aureus enterotoxins-related control strategy.

\section{Competing Interests}

All the authors declare that they have no conflict of interests. None of the authors has a financial or personal relationship with other individuals or organizations that could inappropriately influence or bias the content of this paper. 


\section{Acknowledgments}

This work was jointly supported by the National Natural Science Foundation of China (31371781, 31400794), the Applied Basic Research Programs of Sichuan Province (2014JY0253), and the New Century Excellent Talents in University (NCET11-0847).

\section{References}

[1] R. Rasooly and M. Friedman, "Plant compounds inhibit Staphylococcus aureus bacteria and the toxicity of Staphylococcus Enterotoxin A (SEA) associated with atopic dermatitis," in Atopic Dermatitis-Disease Etiology and Clinical Management, J. Esparza-Gordillo and I. Dekio, Eds., pp. 387-404, InTech-Open Access Publishers, Rijeka, Croatia, 2012.

[2] N. Balaban and A. Rasooly, "Staphylococcal enterotoxins," International Journal of Food Microbiology, vol. 61, no. 1, pp. 110, 2000.

[3] D.-L. Hu and A. Nakane, "Mechanisms of staphylococcal enterotoxin-induced emesis," European Journal of Pharmacology, vol. 722, no. 1, pp. 95-107, 2014.

[4] M. Á. Argudín, M. C. Mendoza, and M. R. Rodicio, "Food poisoning and Staphylococcus aureus enterotoxins," Toxins, vol. 2, no. 7, pp. 1751-1773, 2010.

[5] K. Omoe, D.-L. Hu, H. K. Ono et al., "Emetic potentials of newly identified staphylococcal enterotoxin-like toxins," Infection and Immunity, vol. 81, no. 10, pp. 3627-3631, 2013.

[6] H. K. Ono, Y. Satoo, K. Narita et al., "Identification and characterization of a novel staphylococcal emetic toxin," Applied and Environmental Microbiology, vol. 81, no. 20, pp. 7034-7040, 2015.

[7] A. Kérouanton, J. A. Hennekinne, C. Letertre et al., "Characterization of Staphylococcus aureus strains associated with food poisoning outbreaks in France," International Journal of Food Microbiology, vol. 115, no. 3, pp. 369-375, 2007.

[8] J. Tang, C. Tang, J. Chen et al., "Phenotypic characterization and prevalence of enterotoxin genes in Staphylococcus aureus isolates from outbreaks of illness in Chengdu city," Foodborne Pathogens and Disease, vol. 8, no. 12, pp. 1317-1320, 2011.

[9] X. Yan, B. Wang, X. Tao et al., "Characterization of Staphylococcus aureus strains associated with food poisoning in Shenzhen, China," Applied and Environmental Microbiology, vol. 78, no. 18, pp. 6637-6642, 2012.

[10] K. Omoe, M. Ishikawa, Y. Shimoda, D.-L. Hu, S. Ueda, and K. Shinagawa, "Detection of seg, seh, and seigenes in Staphylococcus aureusisolates and determination of the enterotoxin productivities of $S$. aureus isolates harboring seg, seh, or seigenes," Journal of Clinical Microbiology, vol. 40, no. 3, pp. 857-862, 2002.

[11] J. L. Aguilar, A. K. Varshney, X. Wang, L. Stanford, M. Scharff, and B. C. Fries, "Detection and measurement of staphylococcal enterotoxin-like K (SEl-K) secretion by Staphylococcus aureus clinical isolates," Journal of Clinical Microbiology, vol. 52, no. 7, pp. 2536-2543, 2014.

[12] S. Sharma, "Food preservatives and their harmful effects," Scientific Research Publishing, vol. 5, pp. 1-2, 2015.

[13] Y. Zhao, A. Zhu, J. Tang, C. Tang, J. Chen, and J. Liu, "Identification and measurement of staphylococcal enterotoxin-like protein I (SEll) secretion from Staphylococcus aureus clinical isolate," Journal of Applied Microbiology, vol. 121, no. 2, pp. 539546, 2016.
[14] K. J. Livak and T. D. Schmittgen, "Analysis of relative gene expression data using real-time quantitative PCR and the $2^{-\triangle \Delta C T}$ method," Methods, vol. 25, no. 4, pp. 402-408, 2001.

[15] M. S. Bergdoll, "Staphylococcal intoxications," in Foodborne Infections and Intoxications, H. Reimann and F. L. Bryan, Eds., pp. 443-494, Academic Press, New York, NY, USA, 1979.

[16] F. Shahidi, J. K. V. Arachchi, and Y.-J. Jeon, "Food applications of chitin and chitosans," Trends in Food Science and Technology, vol. 10, no. 2, pp. 37-51, 1999.

[17] Y.-C. Chung, H.-L. Wang, Y.-M. Chen, and S.-L. Li, "Effect of abiotic factors on the antibacterial activity of chitosan against waterborne pathogens," Bioresource Technology, vol. 88, no. 3, pp. 179-184, 2003.

[18] E. I. Rabea, M. E.-T. Badawy, C. V. Stevens, G. Smagghe, and W. Steurbaut, "Chitosan as antimicrobial agent: applications and mode of action," Biomacromolecules, vol. 4, no. 6, pp. 1457-1465, 2003.

[19] H. Liu, Y. M. Du, X. H. Wang, and L. P. Sun, "Chitosan kills bacteria through cell membrane damage," International Journal of Food Microbiology, vol. 95, no. 2, pp. 147-155, 2004.

[20] N. Khan and H. Mukhtar, "Tea and health: studies in humans," Current Pharmaceutical Design, vol. 19, no. 34, pp. 6141-6147, 2013.

[21] D. L. McKay and J. B. Blumberg, "The role of tea in human health: an update," Journal of the American College of Nutrition, vol. 21, no. 1, pp. 1-13, 2002.

[22] S. Kumazawa, K. Kajiya, A. Naito et al., "Direct evidence of interaction of a green tea polyphenol, epigallocatechin gallate, with lipid bilayers by solid-state nuclear magnetic resonance," Bioscience, Biotechnology and Biochemistry, vol. 68, no. 8, pp. 1743-1747, 2004.

[23] Y. Cui, Y. J. Oh, J. Lim et al., "AFM study of the differential inhibitory effects of the green tea polyphenol (-)epigallocatechin-3-gallate (EGCG) against Gram-positive and Gram-negative bacteria," Food Microbiology, vol. 29, no. 1, pp. 80-87, 2012.

[24] M. Hisano, K. Yamaguchi, Y. Inoue et al., "Inhibitory effect of catechin against the superantigen staphylococcal enterotoxin B (SEB)," Archives of Dermatological Research, vol. 295, no. 5, pp. 183-189, 2003. 

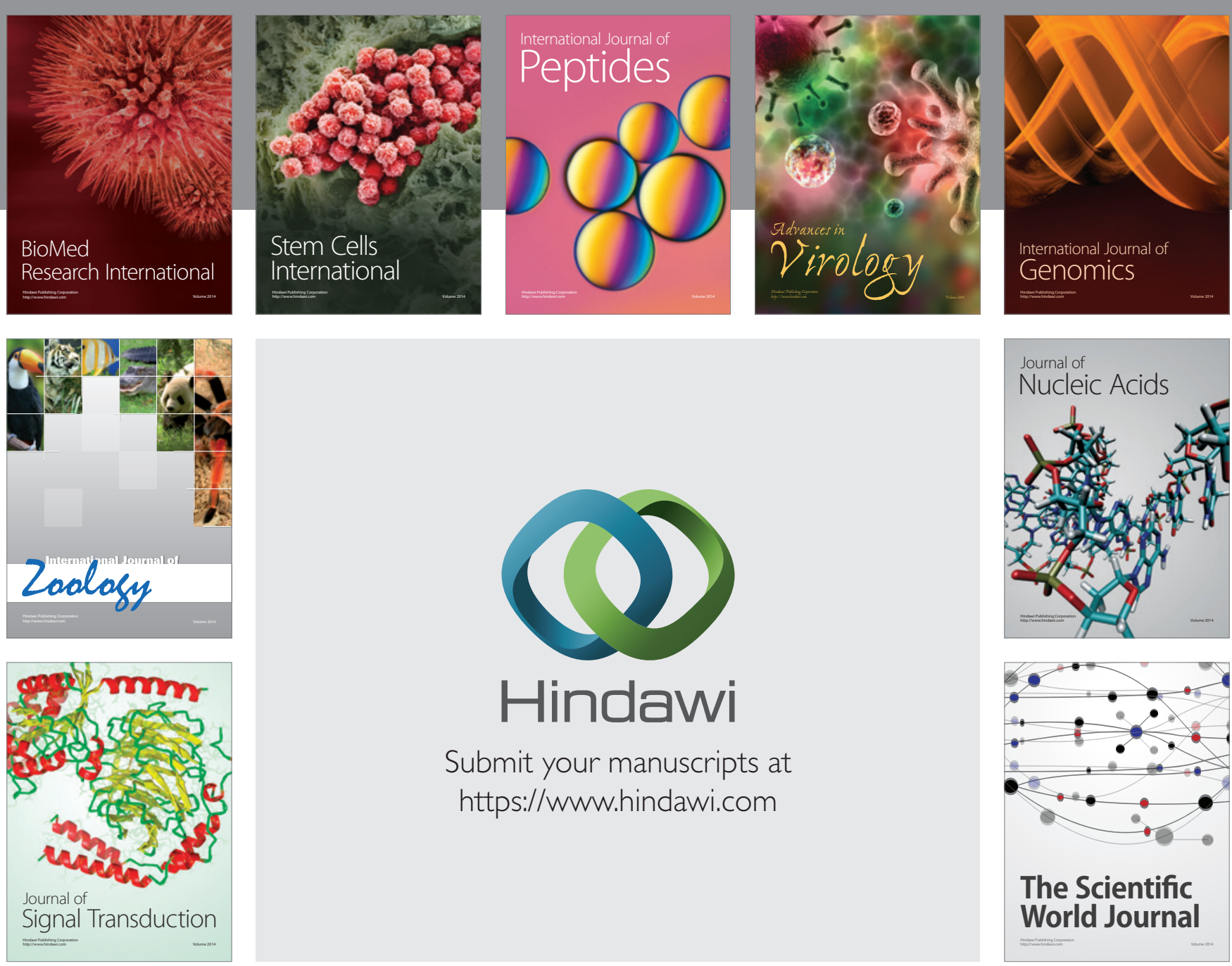

Submit your manuscripts at

https://www.hindawi.com
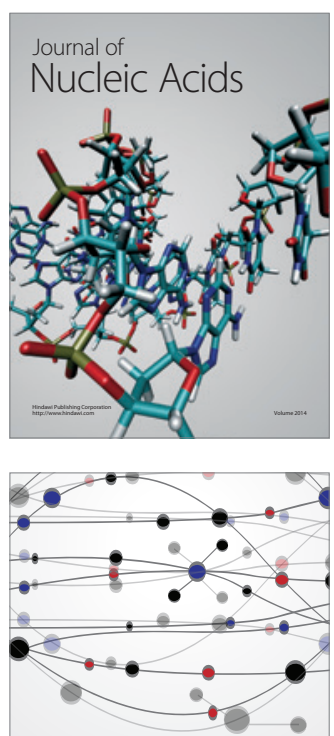

The Scientific World Journal
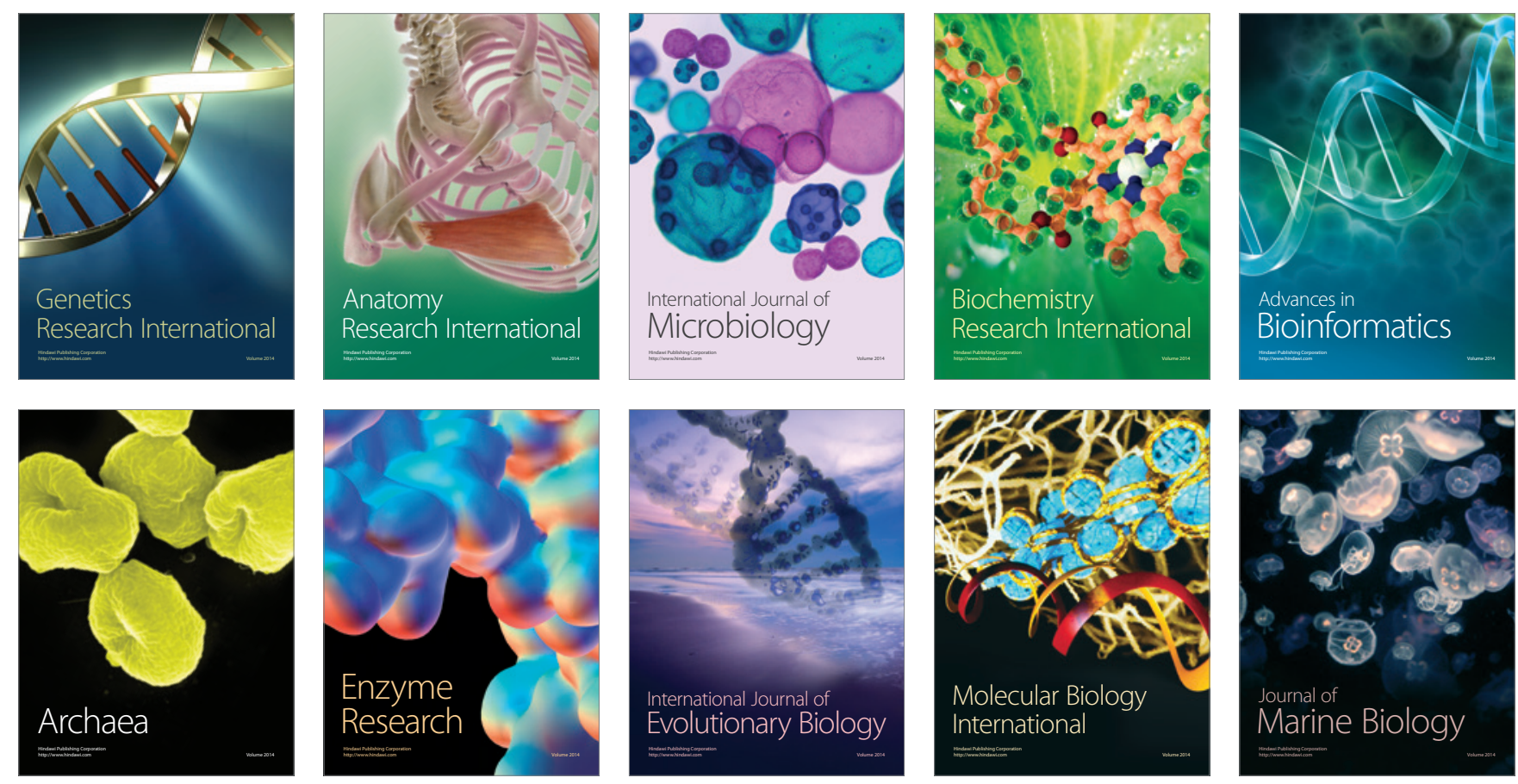